\title{
YHTEISTYÖPELI RYHMÄTYÖN KEHITTÄMISESSÄ
}

\author{
Käytännön kokemusten mukaan huonosti toimivien työryhmien \\ tuottavuus on alhainen, kun taas keskenään toimeentulevien \\ ihmisten ryhmissä saavutukset ovat hyviä. Yksi keino parantaa \\ ryhmän jäsenten välistä vuorovaikutusta ja tätä kautta \\ ryhmätyöskentelyn sujuvuutta ja tuottavuutta, on koulutus. \\ Tätä varten on kehitelty erilaisia simulaatiopelejä, \\ kuten tässä esiteltävä yhteistyöpeli.
}

Kiinnostus ryhmiä kohtaan työn organisoinnin muotona on lisääntynyt voimakkaasti Suomessa viime vuosina. Syynä ovat pääasiassa työn tehostamisvaatimukset. Toimintamallina erityisesti teollisuudessa on pidetty japanilaista tuotantotapaa, ns. Lean-paradigmaa (Wornack ym. 1990). Tiimiajattelua on sovellettu laajasti myös muualla kuin tuotannossa. Ryhmäpohjaisia ratkaisuja on toteutettu esimerkiksi pankki- ja vakuutustoiminnassa, terveydenhoidossa, sosiaalialalla sekä tutkimustyössä (esim. Elovainio 1994, Elovainio \& Sinervo 1994, Engeström 1993, Kortteinen 1992, Saari 1994, Sinervo 1993).

Ryhmässä työskentely ei ole ongelmatonta. Erilaiset itseohjautuvat työryhmät ovat osoittautuneet psykologisesti varsin haavoittuviksi yhteisöiksi, vaikka ryhmän tavoitteellinen tehtävä olisi määritelty selkeästi. Epäonnistumiset ovat johtuneet usein siitä, että ryhmiä perustettaessa ja johdettaessa on keskitytty luomaan vain "teknisiä" edellytyksiä rvhmätoiminnalle, jolloin sosiaaliset ja vuorovaikutukseen liittyvät tekijät ovat jääneet huomiotta. Käytännön kokemusten mukaan huonosti toimivien ryhmien työn tuottavuus on alhainen. kun taas keskenään toimeentulevien ryhmien saavutukset ovat hyviä. (Burbidge 1990, Laitinen ym. 1994, Pulkkis \& Vartiainen 1991, Pulkkis ym. 1991.)

Yksi keino parantaa ryhmän jäsenten välistä vuorovaikutusta, sekä tätä kautta ryhmätyöskentelyn sujuvuutta ja tuottavuutta, on epäilemättä koulutus. Paneutumalla yhteistyön kehittämiseen jo ryhmien perustamisvaiheessa voitaisiin todennäköisesti välttää monia epäonnistumisia. Monet perinteiset opetusmenetelmät, kuten luennot tai ryhmäkeskustelut, tuntuvat kuitenkin yksinään riittämättömiltä yhteistyötaitojen harjoittelemiseen.

Aikuisten oppimisessa on keskeistä koulutuksen liittäminen oppijoiden omaan elämänpiiriin ja omien kokemusten hyödyntäminen. Organisaatioiden ryhmätyökoulutuksessa tarvitaan menetelmiä, jotka mahdollistavat henkilöstön oppimisen oman kokemuksen kautta työkokemusta hyväksikäyttäen lähellä sitä työympäristöä, jossa tiedot ja taidot liittyvät vastaaviin käytännön tilanteisiin. Erilaiset simulaatiopelit ovat esimerkkejä tällaisista menetelmistä.

\section{Mitä simulaatiopelit ovat?}

Simulaatiopeleillä tarkoitetaan pelejä, jotka perustuvat todellisuudesta koottuun malliin. Simulaatiopeleissä suoritetaan pelitoimintoja tiettyjen tavoitteiden saavuttamiseksi simuloiduissa ympäristöissä ja yhteyksissä. Simulaatiopeleille on tunnusomaista $\mathrm{mm}$. se, että ne kuvastavat todellisuutta ja että ne perustuvat osallistujien kommunikaatioon ja vuorovaikutukseen. Simulaatiopeleissä yhdistyvät simulaatioiden ominaisuudet (todellisen järjestelmän keskeiset, kriittiset ominaisuudet omaava, toimiva edustus) sekä 
pelaamisen ominaisuudet (osallistujat, säännöt, kilpailu tai yhteistyö) (esim. Greenblat \& Duke 1981, Saunders ym. 1987, Ruohomäki 1994).

Useimmiten simulaatiopelissä on kyse päätöksenteon harjoittelemisesta monimutkaisissa tilanteissa ja ympäristöissä, jossa osallistujat tekevät valintoja, muotoilevat vaihtoehtoja, toteuttavat niitä ja huomioivat seurauksia tavoitteisiin pyrkiessään. Pelimuotoista simulaatiota voidaan pitää hypoteettisena, tavoitteellisena ja strukturoituna päätöksentekotilanteena, jossa tarkastelun kohteena voi olla esim. ryhmän toiminta ja siihen liittyvät monimutkaiset sosiaaliset prosessit.

Simulaatiopelejä koskeva käsitteistö ei ole vakiintunutta ja määrittelyissä ilmenee epätäsmällisyyksiä. Arkikielessä simulaatiota, pelejä ja simulaatiopelejä ei aina erotella toisistaan. On kuitenkin olemassa simulaatioita, jotka eivät ole pelimuotoisia, esim. lentosimulaattorit. Samoin on paljon erilaisia viihteellisiä pelejä, joissa ei pyritäkään jäljittelemään todellisuutta.

Simulaatiopelit eroavat erilaisista ns. roolipeleistä tai -harjoituksista, joissa osallistujille hahmotellaan vain roolin tai tilanteen yleiset puitteet muun toiminnan ollessa vapaasti ohjautuvaa. Simulaatiopelit ovat yleensä roolipelejä strukturoidumpia ja muodollisempia. Simulaatiopeleissä jäljitellään todellisuuteen perustuvaa dynaamista vuorovaikutusjärjestelmää, jossa roolien esittäminen on vain yksi osa (Greenblat 1988).

\section{Simulaatiopelien käyttö opetuksessa}

Erilaisia pelejä on käytetty opetustarkoituksiin hyvin tuloksin, erityisesti kouluympäristöissä.

Pelejä on alettu Suomessakin enenevästi soveltaa myös työelämässä henkilöstön kehittämisen ja koulutuksen menetelmänä, joista esimerkkejä ovat erilaiset yritys-, johtamis- ja tuotantopelit sekä yrityskohtaisesti räätälöitävät simulaatiopelit esim. toimintaprosessien kehittämiseksi (Ruohomäki \& Vartiainen 1992, Ruohomäki 1994).

Simulaatiopelejä käytetään opetuksessa ja harjoituksessa erityisesti kahteen tarkoitukseen: Ensinnäkin, esittämään monimutkaista todellisuutta monipuolisesti ja konkreettisesti, jolloin osallistujien tehtävänä on kuvata, analysoida ja arvioida todellisuutta, esimerkiksi työtoimintaa. Toiseksi, toimimaan opetusvälineinä, jolloin osallistujien odotetaan kehittävän kognitiivisia, sosiaalisia, affektiivisia ja psykomotorisia taitoja (VanSickle 1978). Perusajatuksena on, että osallistujat kehittävät pelissä tietojaan ja taitojaan, esimerkiksi ryhmätyövalmiuksiaan, joita he sitten soveltavat käytännössä esimerkiksi kouluissa ja työpaikoilla. Tarkoituksena on luoda mahdollisimman hyvät edellytykset opitun siirtovaikutuksen aikaansaamiseksi.

Peleissä osallistujat ovat aktiivisia toimijoita ja oppijoita. Ohjaajan rooliin kuuluu pelitoiminnan ja oppimisen edesauttaminen. Pelit etenevät osallistujien keskustelujen, valintojen ja päätösten mukaan. Oppiminen peleissä tapahtuu oman toiminnan, havainnoinnin, arvioinnin ja kokemusten avulla vuorovaikutuksessa muiden osallistujien kanssa. Pelit mahdollistavat eri näkökulmien käsittelyn ja kokonaisuuksien pelkistetyn havainnollistamisen. Peleissä on mahdollisuus omien tietojen, käsitysten ja toiminnan testaamiseen, seurausten havaitsemiseen ja palautteen saamiseen muilta osallistujilta. Pelissä voidaan harjoitella sosiaalisia taitoja sekä arkipäivän ristiriitatilanteiden ratkaisemista "turvallisissa" olosuhteissa. Opetuskäytännöissä on siirrytty tuotospainotteisesta opetuksesta prosessipainotteisiin menetelmiin, joita simulaatiopelien voidaan katsoa edustavan.

Erilaisilla opetuspeleillä on todettu olevan myönteisiä vaikutuksia osallistujien tiedolliseen oppimiseen, motivaatioon ja kiinnostukseen, kommunikaatioon sekä yhteistyöhön (esim. Greenblat \& Duke 1981,VanSickle 1986, Butler ym. 1988, Ruohomäki 1994). Pelaamalla voidaan lisätä tietoa mm. yhteisistä käsitteistä, yleisistä toimintaperiaatteista ja -vaihtoehdoista sekä (työ)järjestelmien kokonaisuudesta. Pelien avulla voidaan harjoitella tilanteiden arvioimista, ongelmanratkaisua ja yhteistä päätöksentekoa sekä edistää 
vuorovaikutus- ja kommunikointitaitoja. Pelaamisen tulokset voivat ilmetä asenteiden muutoksina, ymmärryksen lisääntymisenä muita henkilöitä ja erilaisia näkökulmia kohtaan.

\section{Simulaatiopelit ja oppiminen}

Simulaatiopelien teoreettisen perustan ja käytännön sovellutusten kannalta keskeisenä lähtökohtana alan kirjallisuudessa on pidetty kokemuksellisen oppimisen ns. Kolb mallia (1984) (Special Issue on Simulation / Gaming for Learning 16, 4, 1986, Miller 188, Thatcher 1990). Pelejä voidaan pitää eräänlaisina "kontrolloituina oppimiskokemuksina", jotka huolellisesti läpivietyinä voivat johtaa tehokkaaseen oppimiseen. Kokemuksellisen oppimisen mallia on sovellettu mm. aikuiskoulutuksessa ja organisaatiopsykologiassa.

Kokemuksellisen oppimisen mallissa (Kolb 1984) tietojen, taitojen ja asenteiden kehittyminen käsitetään oppimisprosessiksi, jonka vaiheita ovat 1. konkreettinen kokemus tapahtumasta (esiin. simulaatiopeli), 2. kokemuksen reflektointi ja tapahtumien havainnointi (esim. yhteisessä jälkipuinnissa pelin jälkeen), 3. niiden abstrahointi ja käsitteellistäminen (esim. yleistysten tekeminen pelikokemuksista), sekä 4. tietojen ja taitojen aktiivinen kokeilu (esiin. käytännön työtilanteissa). Oppimisprosessi edellyttää kaikkien vaiheiden läpikäymistä. Monimutkaisissa tehtävissä kehän eri vaiheita käydään lävitse useaan kertaan, ja mahdollisesti siirrytään laadullisesti uudelle, korkeammalle tasolle.

Kokemuksellisen oppimisen mallissa oppijan omakohtaisella toiminnalla ja tiedon aktiivisella prosessoinnilla on keskeinen osuus. Oppiminen etenee erilaisten tiedollisten ristiriitojen kautta, ja todellisuuteen sopeudutaan sovittamalla yhteen uutta tietoa ja aikaisempaa tietämystä. Oppiminen on jatkuvaa vuorovaikutusta yksilön tietämyksen, sosiaalisen tai kulturaalisen kokemuksen sekä ympäröivän todellisuuden kanssa.

Simulaatiopeleissä osallistujat reflektoivat ja käsitteellistävät kokemuksiaan, kokeilevat tietojaan ja taitojaan, sekä lopulta siirtävät oppimaansa käytännön toimintaan. Oppimisen tehokkuuden ja laadun kannalta olennaista on pelitapahtumien reflektoiniti ns. jälkipuinnissa, jossa täsmennetään käsitteitä ja periaatteita sekä käydään läpi osallistujien pelikokemuksia ja merkityksiä vetäjän tuella. Kokemuksia ulkoistetaan, eritellään, jäsennellään, arvioidaan ja muokataan uudelleen yhdessä muiden osallistujien kanssa keskustelemalla. Pelissä nousseita ajatuksia voidaan muokata abstraktille ja käsitteelliselle tasolle tekemällä kokemuksellisia ja teoreettisia yleistyksiä tapahtumista. Reflektoinnin ja käsitteellistämisen kautta pelikokemuksia liitetään aikaisempiin kokemuksiin ja todellisiin tapahtumiin. Pyrkimyksenä on kehittyneempien tietorakenteiden muodostaminen (esim. Miller 1988, Thatcher 1990, Lederman 1992). Osallistujat voivat aktiivisesti testata oppimiaan asioita pelin kuluessa sekä myöhemmin soveltaa niitä todellisessa toimintakontekstissa.

Kokemuksellisen oppimisen prosessi voidaan liittää simulaatiopelin tyypillisiin vaiheisiin, joita ovat johdanto peliin, varsinainen pelaaminen sekä jälkipuinti ja yhteenveto (Miller 1988) (Kuva 1).

Viime vuosikymmenenä voimakkaasti kehittynyt konstruktivistinen oppimiskäsitys johtaa samantapaisten periaatteiden korostamiseen kuin mitä kokemuksellisen oppimisen mallissa simulaatiopelien yhteydessä on esitetty. Konstruktiivisen näkemyksen mukaan oppimisessa keskeistä on tavoitteisuus, tiedon aktiivinen prosessointi ja reflektiivisyys. Tällöin yksittäisten tietojen ja taitojen opettaminen ja oppimisen kontrolli eivät enää riitä, vaan opetuksen tavoitteeksi tulee herättää oppijoissa aktiivisia tiedon konstruointiprosesseja. (Rauste-von Wright 1994, von Wright, J. ja Rauste-Wright, M. 1992). Simulaatiopelit voidaan nähdä yhtenä tapana luoda "oppimisympäristöjä", jotka tukevat oppijan omaa rakentelevaa, tilannesidonnaista tiedon prosessointia. 


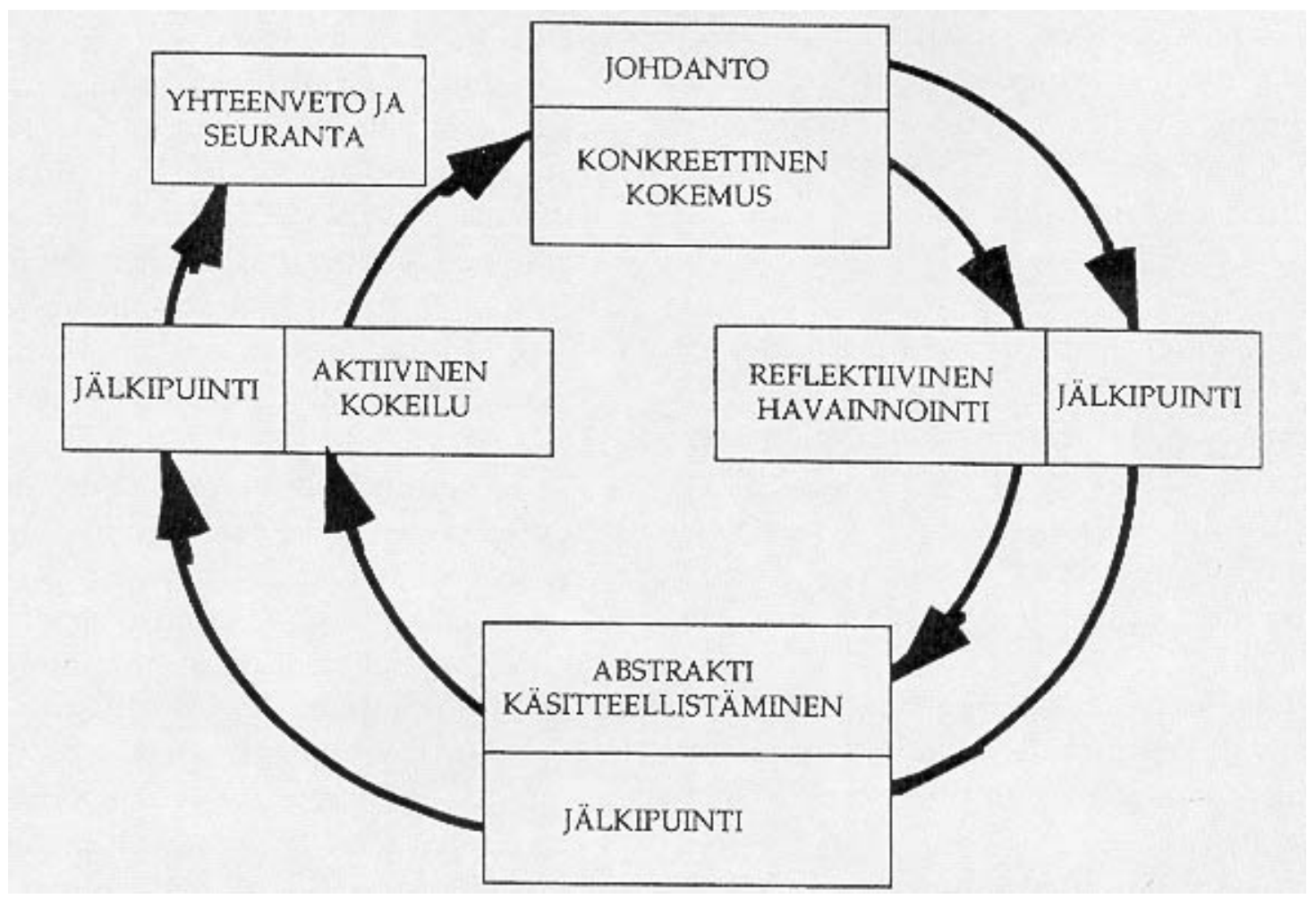

Simulaatiopelejä voidaan pitää yhtenä ns. aktivoivan opetuksen menetelmä, jossa vastuu oppimisesta siirretään opiskelijalle ohjaajan tukiessa oppimisprosessia. Aktivoivat opetusmenetelmät perustuvat toisaalta prosessipainotteiseen ajatteluun ja toisaalta konstruktiiviseen käsitykseen muistista ja oppimisesta. Oppiminen nähdään informaation valikointina, tulkintana ja tiedon aktiivisena tuottamisena. Oppiminen ei ole vain faktojen tallentamista, vaan olennaista on oppijan aktiivinen panos, kun hän yrittää rakentaa oppimastaan merkityksellisiä kokonaisuuksia (vrt. Lonka \& Lonka 1991).

Simulaatiopeliä voidaan tarkastella myös yhtenä yhteistoiminnallisen oppimisen menetelmänä, mikäli peli on rakennettu niin, että pelaajien välille syntyy positiivinen keskinäinen riippuvuus, esimerkiksi yhden hyötyessä muutkin hyötyvät tai yhdessä toimimalla voidaan saavuttaa parempia tuloksia kuin yksin. Yhteistoiminnallisella oppimisella tarkoitetaan yhdessä työskentelyä yhteisten tavoitteiden saavuttamiseksi, jossa periaatteina ovat positiivinen riippuvuus muista sekä vuorovaikutustaitojen harjoitteleminen ja edistymisen arvioiminen yhdessä (Johnson \& Johnson 1987).

\section{Yhteistyöpeli: Tavoitteena valmiudet työskennellä ryhmissä}

Yhteistyöpeliä *(ks. sivu 34) käytetään harjoiteltaessa ryhmätyötaitoja osana laajempaa organisaation kehittämistä ja ryhmätyökoulutusta, jossa luodaan esim. yhteisiä suuntaviivoja ja toimintaperiaatteita myöhemmälle ryhmässä toimimiselle- Yhteistyöpeli on tarkoitettu käytettäväksi organisaatioissa sekä uusia ryhmiä muodostettaessa että jo olemassa olevien ryhmien toimintaa kehitettäessä.

Yhteistyöpelillä on tarkoitus kehittää osallistujien valmiuksia työskennellä ryhmissä ja siten edistää ryhmien toimintaa ja tuottavuutta. Pelaamalla luodaan yhteistä perustaa ryhmässä työskentelemiselle. Tavoitteena on pitkällä aikavälillä auttaa ryhmän muodostusta ja ennaltaehkäistä epäonnistumisia.

Yhteistyöpelin tavoitteita ovat:

* osallistujien tutustuminen toisiinsa ryhmän jäseninä

* yhteistyö- ja vuorovaikutustaitojen kehittäminen 
* ryhmäilmiöihin tutustuminen ja yhteisten käsitteiden muodostuminen

* vaikeiden tilanteiden ennakoinnin kehittäminen

* ryhmätyössä ilmenevien ongelmien tunnistamisen ja ratkaisemisen harjoitteleminen palautteen saaminen yhteisestä ongelmanratkaisusta

* perustan luominen yhteisille toimintaperiaatteille ryhmässä.

Yhteistyöpeli on suunnattu toimistojen, hallinnon ja teollisuuden operatiivisen tason henkilöstölle, jotka tulevat muodostamaan tai jo muodostavat ryhmän. Peliä voidaan käyttää erilaisten toimisto- (esim. ryhmäpohjainen asiakaspalvelu) ja teollisuusryhmien (esim. tuotantoryhmät) koulutuksessa. Osallistujien lukumäärä peliin kerrallaan voi olla kolmesta kahdeksaan.

Pelin vetäjänä voi toimia organisaation ulkopuolinen kouluttaja tai kehittäjä. tai organisaation sisäinen kehittäjä, esim. henkilöstökouluttaja. Pelin vetäjältä edellytetään kokemusta ja taitoa ryhmien vetämisestä sekä tottumusta työelämän ongelmien käsittelyssä. Osallistuminen pelin vetäjille tarkoitettuun koulutukseen on suotavaa.

\section{Yhteistyöpelin kokonaisuus}

Yhteistyöpeli on tarkoitettu osaksi laajempaa ryhmätyökoulutuksen kokonaisuutta. Se voidaan jakaa kolmeen osaan, joita ovat yhteistoiminnan kartoitus, varsinainen pelaaminen jälkipuinteineen ja ryhmän toimintaperiaatteiden luominen (taulukko 1).Tarkoituksena on osien läpikäynti ko. järjestyksessä esim. parin päivän mittaisena tiiviinä kokonaisuutena tai osina pitemmän ajanjakson aikana. Pitempi ajanjakso mahdollistaa ryhmän toimintaperiaatteiden käsittelyn syvällisemmän työstämisen ja aiheiden pohtimisen. Ryhmätyötaitojen kehittäminen Yhteistyöpelin avulla onnistuu parhaiten, kun se liitetään osaksi laajempaa organisaation ja henkilöstön kehittämistä.

Työyhteisön tilanteeseen tulee tutustua mahdollisimman monipuolisesti jo ennen Yhteistyöpelin käytöstä päättämistä, esimerkiksi keskustelemalla johdon edustajien kanssa, haastattelemalla henkilöstöä, havainnoimalla ja valmiisiin dokumentteihin tutustumalla. Lisäksi voidaan käyttää myös pelin yhteydessä toimitettavaa erillistä yhteistyökyselyä. Mikäli peliä päätetään käyttää, voidaan saatujen tietojen pohjalta peliä "räätälöidä" kohderyhmän tilannetta vastaavaksi.

Pelaaminen etenee kysymyskorttien pohjalta keskustellen, kantaaottaen ja ongelmia ratkoen. Pelissä vetäjän rooli on keskeinen. Hän pyrkii luomaan turvallisen ilmapiirin, kannustaa osallistujia aktiivisesti keskusteluun sekä huolehtii pelin rytmityksestä ja yleisestä sujumisesta.

Jälkipuinnissa tarkastellaan vetäjän tuella yhdessä keskustellen, mitä pelissä tapahtui ja millaiset olivat osallistujien kokemukset. Keskustelussa pelitapahtumia tarkastellaan eri osallistujien näkökulmista ja niitä verrataan todellisiin kokemuksiin ryhmätyöskentelystä.

Ryhmäkoulutuksen kolmannessa vaiheessa pelissä opittuja asioita pyritään soveltamaan todellisissa tehtävissä. Tavoitteena on käynnistää ryhmän toimintaperiaatteiden luominen. Kysymys on ryhmän ja organisaation välisestä II sopimuksesta", jossa määritellään ryhmän oikeudet ja velvollisuudet. Periaatteita luotaessa voidaan joko selkeyttää nykyistä käytäntöä ja luoda toimintasääntöjä ongelmallisiksi koettuihin asioihin tai säännöt voivat olla selkeästi osa uuden, kehittyneemmän toimintatavan rakentamista.

\section{Sisältö ja käytettävät käsitteet}

Yhteistyöpelin perusajatuksena on, että ryhmätyöskentelyn ilmiöt, teemat ja käsitteet havainnollistetaan työntekijöille tuttujen työtilanteiden tasolle. Arkitilanteista nousevia kysymyksiä ja ongelmia käsitellään pelikorttien avulla yhdessä keskustellen ja kantaaottaen. Näin uusillekin asioille on löydettävissä yhteys osal- 
listujien aikaisempiin työkokemuksiin. Käytännönläheisesti ja oman kokemuksen kautta opittuja asioita on vastaavasti helppo siirtää todelliseen ryhmätoimintaan työpaikalla.

Taulukko 1. Ryhmäkoulutuksen osat

\begin{tabular}{|l|l|l|}
\hline \multicolumn{1}{|c|}{ KOULUTUKSEN OSAT } & TOTEUTUSTAPA & KESTO \\
\hline I Yhteistoiminnan kartoitus & $\begin{array}{l}\text { Yhteistyökysely, haastattelut, } \\
\text { keskustelut }\end{array}$ & $2 \mathrm{~h}$ \\
\hline II Pelaaminen ja jälkipuinti & $\begin{array}{l}\text { Keskustelua ja ongelmanratkaisua } \\
\text { kysymyskorttien avulla peli- } \\
\text { välineitä pelilauta, noppa, } \\
\text { nappulat ja tulostaulu. }\end{array}$ & $\begin{array}{l}3-4 \mathrm{t}, \text { josta } \\
\text { jälkipuinti } \\
\text { noin 1/2 t. }\end{array}$ \\
\hline $\begin{array}{l}\text { III Ryhmän toimintaperiaat- } \\
\text { teiden luominen }\end{array}$ & $\begin{array}{l}\text { Ohjattu ryhmäkeskustelu } \\
\text { ryhmätyön teemoista ja } \\
\text { toimintaperiaatteista }\end{array}$ & $\begin{array}{l}4 \mathrm{~h}-1 \\
\text { päivä }\end{array}$ \\
\hline
\end{tabular}

\section{Kuva 2. Yhteistyöpelin osa-alueet}

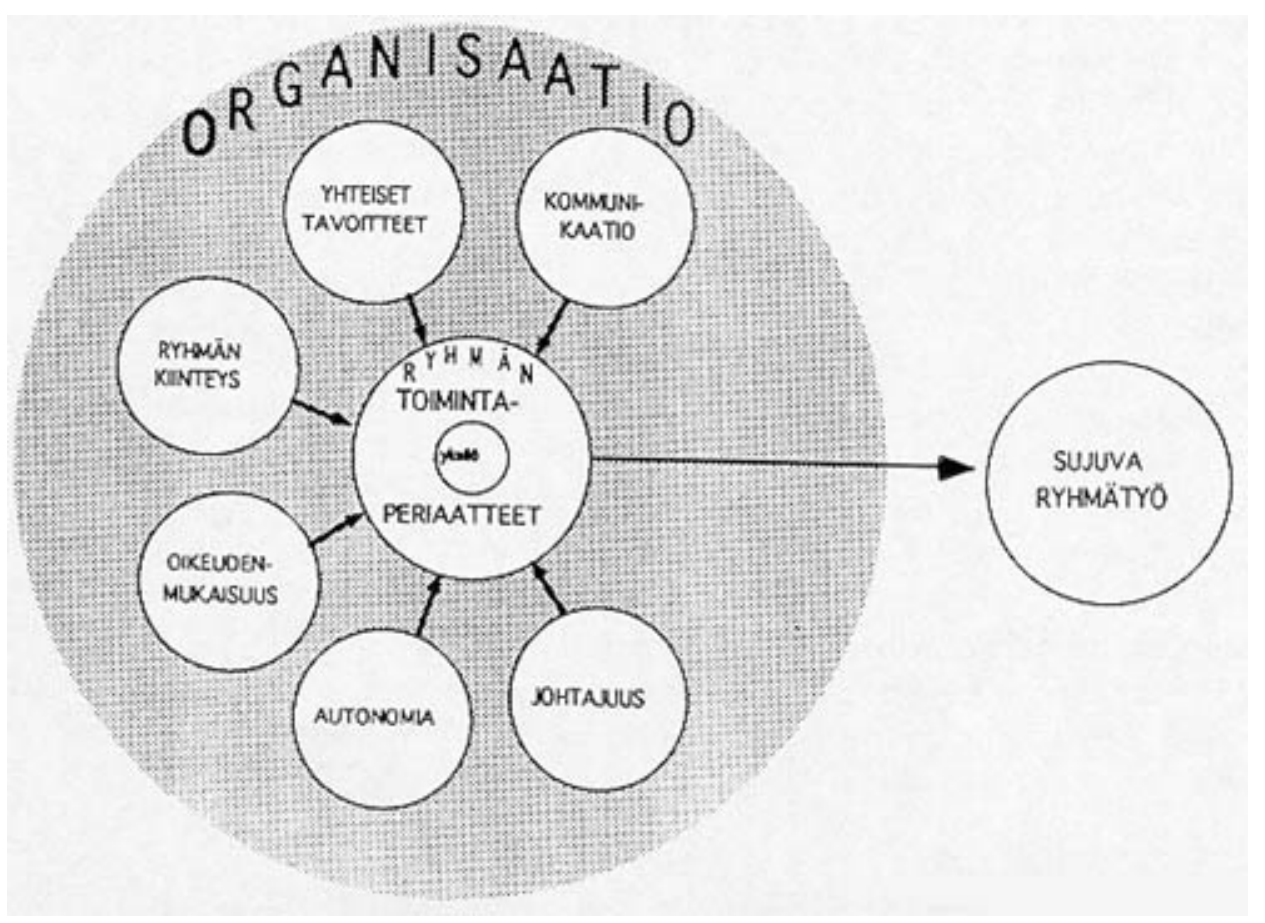

Pelissä käydään läpi tyypillisiä ryhmätyössä esiintyviä teemoja, joita on kohdattu suomalaisissa ryhmien ja organisaatioiden kehittämishankkeissa sekä tuotu esiin alan kirjallisuudessa. Tällaisia ilmiöitä tai teemoja ovat: kommunikaatio, ryhmän tavoitteet, ryhmän kiinteys, oikeudenmukaisuus, autonomia ja johtajuus (esim. Hackman 1990, Helkama 1981, 1991, Laitinen ym. 1994, Salminen 1987, Sulander 1992) (Kuva 2).

Ryhmätyötä lähestytään pelissä moniulotteisesti. Yhteistyötä tarkastellaan pelissä kolmelta tasolta: ryhmä osana laajempaa työ- ja toimintajärjestelmää, ryhmän sisäinen toiminta sekä ryhmä yksilön kannalta (Kuva 2). Pelissä pyritään jäljittelemään ryhmän kehitysvaiheita, joita ovat muotoutumisvaihe, ristiriitavaihe, toimintaperiaatteiden syntymisen ja kypsän toiminnan kausi.

Yhteistyön sujuminen edellyttää muiden ryhmän jäsenten toiminta- ja ajattelutapojen sekä arvostusten ymmärtämistä ja erilaisuuden sietämistä. Käsitykset ryhmän jäsenistä muokkautuvat yhteisten kokemusten myötä. Yhteistyöpelissä käsitellään toisten ryhmän jäsenten tuntemiseen liittyviä kysymyksiä (esim. Fiske \& Taylor 1984). 


\section{Käyttökokemuksia}

Yhteistyöpeliä oli testattu vuoden 1994 lokakuun loppuun mennessä pelin kehittäjien toimesta 16 työpaikalla, joissa yhteensä 36 ryhmää ja yli 250 henkilöä osallistui peliin. Kokeiluja on tehty teollisuudessa (esim. Ahlströmin pumpputehdas, Enso/Pakenso, Yhtyneet paperitehtaat/Kaipola) ja toimistotyöpaikoilla (esim. Helsingin yliopiston hallintovirasto, Postipankki, Sampo).

Yhteistyöpeliä koskevat osallistujien arviot, joita on koottu välittömästi pelin jälkeen kyselyillä ja ryhmähaastatteluilla, ovat olleet myönteisiä. Suurin osa vastanneista tunsi mielialansa pelin jälkeen myönteiseksi ja piti pelaamista hyödyllisenä. Lähes kaikki arvelivat, että pelistä voisi olla hyötyä yhteistyön kehittämisessä omalla työpaikalla.

Kokemukset ovat siis olleet kannustavia:

- Osallistuminen on ollut innostunutta

- Pelissä käsitellyt asiat ovat vastanneet työpaikan arkea

- Toisiin tutustumista on pidetty arvokkaana

- Peli on auttanut erilaisten näkemyksien esille saamista, keskustelu on ollut avointa ja rakentavaa

- Peli on helpottanut keskustelua vaikeistakin asioista

- Pelissä ryhmätyön ongelmiin on löytynyt uusia ratkaisuvaihtoehtoja.

Tulevaisuudessa tutkimuksellisia haasteita ovat $\mathrm{mm}$. pelissä tapahtuvan kommunikaation ja ongelmanratkaisun tarkastelu sekä pelin oppimisvaikutusten selvittäminen. Oletuksena on, että käytännönläheisesti ja oman kokemuksen kautta opittuja asioita on helppo siirtää ryhmän todelliseen toimintaan työpaikoilla. jatkossa haasteena onkin, pelin välittömien vaikutusten lisäksi, kerätä tietoa pelin siirtovaikutuksista ryhmätyön todelliseen kehittymiseen. Yhteistyöpelin merkitystä ja roolia olisi tarpeellista tarkastella osana laajempaa kehittämisen kokonaisuutta.

* Yhteistyöpelin ovat suunnitelleet Virpi Ruohomäki, Paul Buhanist, Matti Laitinen, Juhani Sulander, Tiina Tanskanen ja Matti Vartiainen Teknillisen korkeakoulun Työpsykologian laboratoriosta, Otakaari 4 A, 02150 Espoo.

\section{IÄHTEET}

Butler, R. J., Markulis, P. M. \& Strang, D. R.. 1988. Where are we? An analysis of the metbods and focus of the research on simulation gaming. Simulation and Games, 19, 1, 3-26

Burbidge, J. 1990. Group technology tbe state of art Esitelmä Teollisuusautomaatioinstituutin jatkokoulutuskurssilla.

Elovainio, M. 1994. Ryhmät ja tiimit työssä. Teoksessa: Lindström, K (Toim.) Terve työyhteisö - kehittämisen malleja ja menetelmiä. Työterveyslaitos.

Elovainio, M. ja Sinervo, T. 1994. Vanhainkotien kehittämisen seurantatutkimus. Stakes sosiaali- ja terveysalan tutkimus-ja kehittämiskeskus. Raportteja (painossa).

Engeström, Y. 1993. Moniammatillisten tiimien toiminnan analysointi. Teoksessa: Simoila, R.., Harlamov, A., Launis, K., Engeström, Y. , Saarelma, O. ja Koskinen-Jussila, A.. I.. (Toim.) Mallit, kontaktit, tiimit ja verkot. *Välineitä terveyskeskustyön analysointiin. Toimiva terveyskeskus - projektin viides osaraportti. Stakes sosiaali- ja terveysalan tutkimus-ja kehittämiskeskus. Raportteja 80.

Fiske, S. T. \& Taylor, S. E. 1984. Social Cognition. New York.. Random House. 
Greenblat, C. S. \& Duke, R.. D. (Eds.) Principles and practices of gaming-simulation. London: Sage.

Hackman, J. R.. (Toim) 1990. Groups that work (and those that don't): Creating conditions for effective teamwork. San Francisco:Jossey Bass.

Helkama, K. 1991.Ryhmätoiminta ja proseduraalinen oikeudenmukaisuus. Teoksessa: Pulkkis, A. ja Vartiainen, M.. (Toim.) Muuttuva organisaatio - kehittyvä ryhmätyö, 1-11. TKK, Teollisuustalous ja Työpsykologia, raportti no 137, Otaniemi.

Helkama, K. 1981. Ryhmätyöskentelyn teoreettisia perusteita. Valtion koulutuskeskus, julkaisusarja B no 15. Valtion painatuskeskus. Helsinki.

Kolb, D. 1984. Experiental learnin .Experience as the source of learning New Jersey: Prentice Hall.

Kortteinen, M. 1992. Kunnian kenttä - Suomalainen palkkatyö kulttuurisena muotona. Hanki ja jää. Hämeenlinna.

Johnson, D. \& Johnson, R.. 1987. Joining together Group Theory and Group Skills. Third edition. New Jersey: Prentice Hall.

Laitinen, M., Vartiainen, M., Pulkkis, A.. ja Sulander, J. 1994. Työntekijän ja ryhmän autonomia työssä. Psykologia 3, 29, 186-194.

Lederman, L. G. 1992. Debriefing: Toward a Systematic Assesment of Theory and Practice. Simulation and Gaming, $23,2,145-160$.

Lonka, K\& Lonka, L (toim.) 199].Aktivoiva opetus. Käsikiija aikuisten ja nuorten opettajille. Helsinki: Kiilaybtymä.

Miller, A. 1988. Who would like to sbare their experiences? Debriefing and experiental learning. In:Saunders, D, Coote, A. \& Croocall, D. (Eds.) Learning from Expert . ence tbrougb Games and Simulations, 23-33. Cardif:. Sagset.

Pulkkis, A. ja Vartiainen, M. (Toim.) 1991. Muuttuva organisaatio - kehittyvä ryhmätyö. Teknillinen korkeakoulu, Teollisuustalous ja Työpsykologia, raportti no 13 7, Otaniemi.

Pulkkis, A., Vartiainen, M.., Sulander, J. ja Laitinen, M. 1993. From production groups to productive group work. Proceedings of the 12th international conference on production research. Lappeenranta, Finland, 16-20 August Elsevier Amsterdam-London-New York-Tokio.

Randel, J., Morris, B., Wetzel, C. \& Wbitebill, B. 1992. The Effectiveness of Games for Educational Purposes: A Review of Recent Research. Simulation \& Gaming 23, 3, 261-275.

Rauste-von Wright, M 1994. Opetussuunnitelma ja oppimiskäsitys. Teoksessa Kajanto, A.. ja Tuomisto, J. (Toim). Elinikäinen oppiminen. Vapaan sivistystyön 35. vuosikirja. Kansanvalistusseura ja Aikuiskasvatuksen Tutkimusseura. Jyväskylä. Gummerus.

Ruohomäki, V 1994. Simulaatiopelit ja niiden vaikutukset- Työnkulkupeli hallinnollisen työn kehittämisessä. Teknillinen korkeakoulu, Teollisuustalous ja Työpsykologia, raportti no 156, Otaniemi.

Ruohomäki, V\& Vartiainen, M. 1992. (Toim.) Simulaatiopelit oppivan organisaation koulutusvälineinä. Teknillinen korkeakoulu, Teollisuustalous ja työpsykologia, raportti no 140, Otaniemi.

Saari, E 1994. Voidaanko tutkimusryhmiä perustaa? Tapaustutkimus Valtion teknillisen tutkimuskeskuksen metallilaboratorion ryhmäkokeilusta vuosina 1989-1991. Lisensiaatintutkimus. Helsingin yliopiston Kasvatustieteen laitos.

Salminen, S. 1987. Relationships between cohesion and success in ice hockey teams. Scandinavian Journal of Sport Science, 9, 1, 25-32. 
Saunders, D., Coote, A. \& Croocall, D. (Eds.) Learning from experience through Games and Simulations, 8-11. Cardiff.. Sagset.

Sinervo, T. 1993. Työn raskaan viihtyjät. Sosiaalialan työntekijät ja työn organisointi. Stakes sosiaali-ja terveysalan tutkimus-ja kehittämiskeskus. Raportteja 111.

Sulander J. 1992. Oikeudenmukaisuus tuotantoryhmissä. Tutkielma, Helsingin yliopiston Sosiaalipsykologian laitos.

Thatcher D. 1990. Experience as Learning: Implications for Training and Operation. Simulation / Games for Learning, 20, 3, 276-302.

VanSickle, R.. L. 1978. Designing simulation games to teach decision-making skills. Simulation and Games 9, 4, 413-428.

VanSickle, R.. L. 1986.A quantitative review of research on instructional simulation gaming: a twenty-year perspective. Theory and Research in Social Education, XIV 3, 245-264.

Womack, J., Jones, D. ja Roos, D. 1990. The machine that changed tbe world. Rawson Associates, MacMillan Publishing Company. New York.

von Wright, J. \& Rauste-Wright, M. 1992. Humanistinen psykologiaja kokemuksellinen oppiminen. Aikuiskasvatus 4, 210-214. 